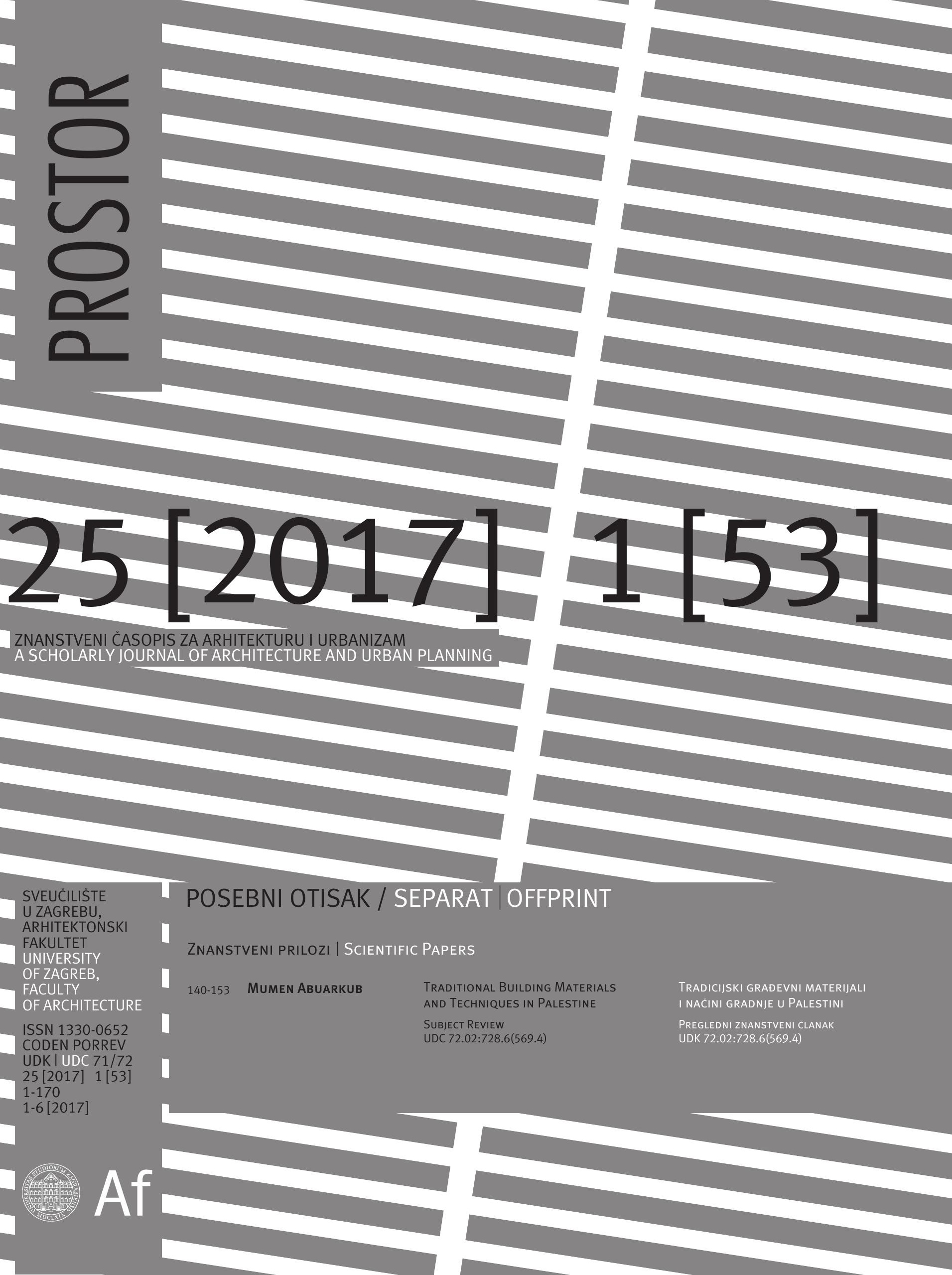


FIG. 1 BUILDING A TRADITIONAL STONE HOUSE in a PALEStinian VILLAGE

SL. 1. GRADNJA TRADICIJSKE KAMENE KUCE U PALESTINSKOM SELU

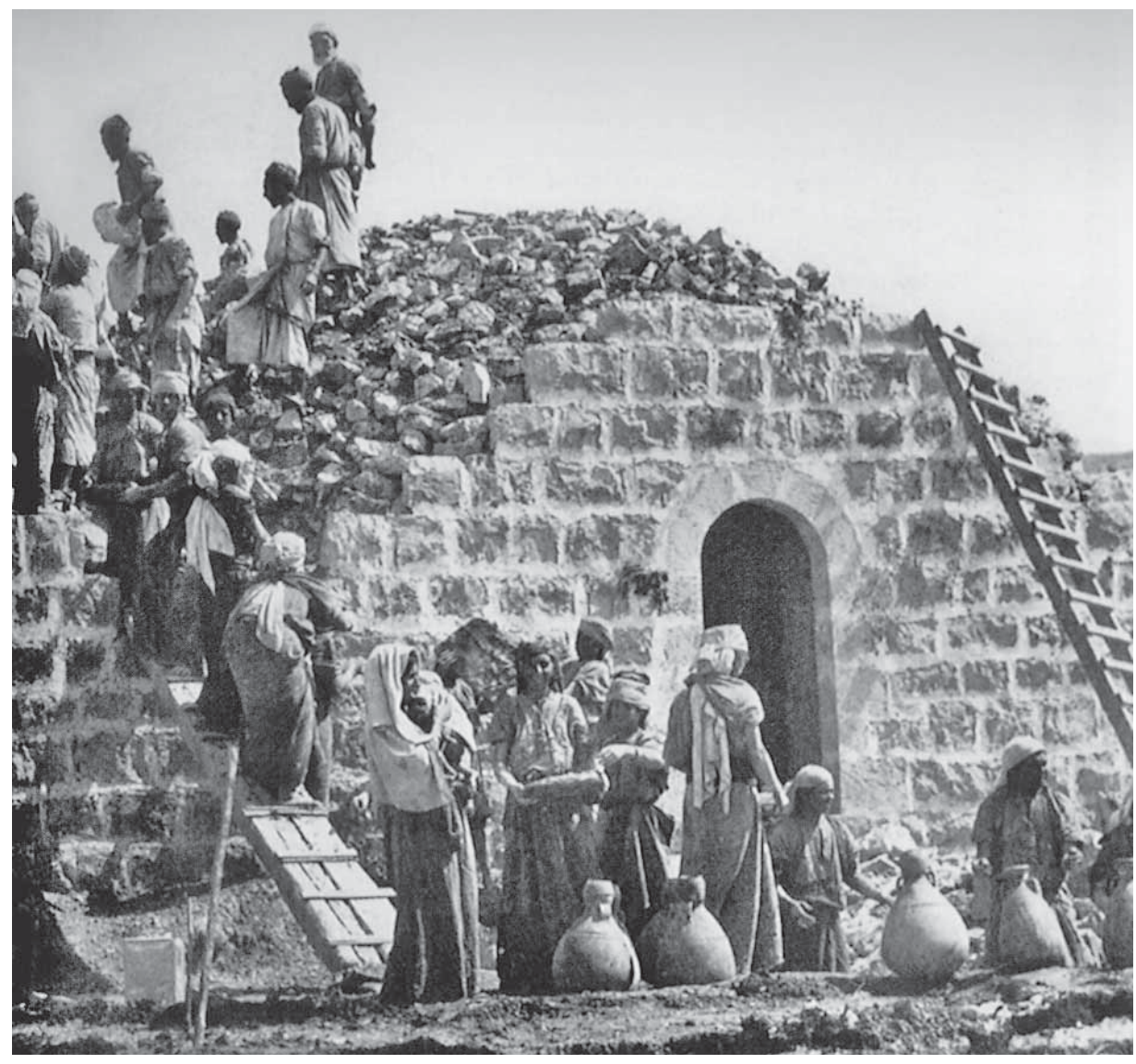




\section{Mumen Abuarkub}

Fon UNIVERSITY, FACULTY OF ARCHITECTURE REPUBLIC OF MACEDONIA - 1000 SKopJe

mumen.abuarkub@yahoo.com

SubjeCt ReVIeW

UDC 72.02:728.6(569.4)

TeCHNical SCiences / Architecture and URban Planning

2.01.03. - Architectural Structures, Building Physics, MATERIALS AND BUILDING TECHNOLOGY

Article ReCeived / AcCepted: 28. 8. 2016. / 13. 6. 2017.
SVEUĊILIŚTE FON, ARHITEKTONSKI FAKULTET

REPUBLIKA MAKEDONIJA - 1000 SKOPJE

mumen.abuarkub@yahoo.com

PREgLEDNI ZNANSTVENI ČLANAK

UDK 72.02:728.6(569.4)

TEHNICKE ZNANOSTI / ARHITEKTURA I URBANIZAM

2.01.03. - ARHITEKTONSKE KONSTRUKCIJE, FIZIKA ZGRADE, MATERIJALI I TEHNOLOGIJA GRADENIA

ČLANAK PRIMLJEN / PRIHVACEN: 28. 8. 2016. / 13. 6. 2017.

\section{Traditional BuIlding Materials and TECHNIQUES in PALESTINE}

\section{TRADICIJSKI GRAĐEVNI MATERIJALI I NAČINI GRADNJE U PALESTINI}

DOME

FOUNDATIONS

OPENINGS

ROOFING

VAULTS

WALLS

The study examines building techniques and distinct architectural elements: foundations, walls, openings, vaults, cupolas, roofing. It elaborates how building size and choice of materials affect building practice, focusing on technical standards, describing basic building materials and traditional construction methods for each architectural element of Palestinian traditional house.

\author{
KUPOLA \\ TEMELJI \\ OTVORI \\ KROVIŚTA \\ SVODOVI \\ ZIDOVI
}

U radu se istrażuju načini gradnje i različiti graditeljski elementi: temelji, zidovi, otvori, svodovi, kupole, krovišta. Analizira se na koji način veličina zgrade i izbor materijala utječu na graditeljsku praksu s osobitim naglaskom na tehničke standarde i opis temeljnih građevnih materijala i tradicijskih načina gradnje za svaki graditeljski element tradicijske palestinske kuce. 


\section{INTRODUCTION}

\author{
UVOD
}

\footnotetext{
C
} onstruction has a very important position in community development. It reflects the way of building, new materials and new technologies. The use of building materials in general largely depends on the country resources, countries that have abundance of some kinds of building materials use them extensively in building construction.

The actual interest of the Palestinian architectural heritage began in the eighties of the last century, where a number of interested people and Palestinian researchers, architects and non-architects, prepared studies and research works showing the importance of the Palestinian architectural heritage and the need to document and preserve it. There is no doubt that the presence of architectural faculties at the Palestinian Universities and the spread of research centers that are concerned in documenting the Palestinian cultural heritage has contributed significantly to raising the awareness and interest in architectural heritage and it's preservation.

There are few studies and writings about traditional building methods in Palestine, some written by specialized architects and others by interested people, some Palestinian and some foreigners, who are keen about this heritage. Palestinian studies and writings on the other hand have appeared relatively recent, and the greater part of them has recently been released in the past years. Some foreign studies date back to the early twentieth century.
This research, traditional building methods in Palestine, is mainly aimed at defining in detail the building methods that were used in Palestine. This study constitutes a base or opening to other studies and in-depth research about building methods and construction materials that were used in different geographical areas in Palestine. It is an episode of a long series of studies aimed mainly in documenting, analyzing and understanding the Palestinian architectural heritage. Such studies are not easily achieved, especially under the current conditions in which the Palestinians endure, which prevent coverage of all historical Palestinian areas.

This study mainly relied on fieldwork, in addition to writings and published studies that mostly covered areas of the West Bank, as it appears from the list of references that were the basis for this research. The study also relied on office research in the relevant publications, and adopted a systematic field research and field visits to various regions in Palestine. With the help of these researches, various models of construction blueprints were documented for areas that varied geographically and climatically in addition to interviews with constructivist veterans who conveyed the history and the construction methods used in Palestine.

It must be noted that no one would be able to document and analyze traditional building methods in Palestine alone. This work requires further joint efforts and cooperation between researchers and concerned institutions in order to do organized scientific studies to cover all the Palestinian territories through documentation, analysis, and field surveys. This should be done as quickly as possible, as this cultural heritage is declining year after year because of the demolition, negligence, and the lack of awareness of the importance of this heritage and its preservation.

Building processes are connected directly to the prevailing habits and traditions in Palestine; the action of building depends on community participation and the concept of "help" which distinguishes the Palestinian society in all matters.

\section{TRADITIONAL BUILDING MATERIALS}

\section{TRADICIJSKI GRADEVNI MATERIJALI}

Before the second half of the $20^{\text {th }}$ century, stone was the main material in traditional buildings, except in Jordan Valley. All buildings built in Palestine had lime-based (gypsum-based) mortars. Cement and reinforced concrete were new techniques invented in

\footnotetext{
1 HADID, 2002: 18

2 HADID, 2002: 18
} 
the West Bank and Gaza Strip. Therefore, all traditional buildings in Palestine were built without cement. Lime, mud and gypsum were the traditional binders used by masons for centuries in Palestine.

More than 50,000 buildings have been registered in the National Register for the traditional architectural buildings done by Riwaq - Center for Architectural Conservation. The register information shows that stone was the main building material in West Bank Mountains and in some Gaza's buildings, while mudstone was used in Jordan valley and in the coastal plain of Gaza.

Palestinian Stones - The stone is the oldest and mostly used construction material in Palestine despite the appearance of numerous and newer construction materials. The stone has always been present while using different decorative materials for exterior and interior surfaces, vertically or horizontally, thus the stone has always been a big challenge for the architects as well as the aesthetics. In Palestine, main kinds of stone that were used for building a stone house are: limestone (used in the central mountains areas) and sandstone (used in the coastal plain).

- Limestone - The characteristics of the stone in the central mountains vary with localities. The traditional classification of limestone in the area is based on use rather than the origin. The soft stones are: Ka'kuleh soft whitish stone (mainly Calcium Carbonated); Nari - a very inhomogeneous white stone, lighter than other chalks and limestone, which is not a good quality stone for general building purpose. The hard stones are: Malaki (when quarried it is pure white and easy to work, it hardens on exposure to air and may become yellowish, this stone is considered as the best for building purpose); Mizzi: it has three different varieties (weight $2480 \mathrm{~kg} / \mathrm{m}^{3}$ ): Mizzi Ahmar - it is hard, light yellow and irregularly streaked by red bands; Mizi Hilu - whitish and yellow veins; Mizzi Yahudi - it is a gray limestone, the hardest and the best building stone. ${ }^{1}$

- Sandstone - The sandstone is found in outcrops along the coast. The coastal cities were built on these outcrops using the sandstone as building material. Kurkar is porous, inhomogeneous, relatively young sandstone. It is easy to quarry and dress, but behaves badly to weather; this is the reason why they used to plaster the exterior walls. Sandstone was used as a building material in all the buildings made from stone in Gaza Strip.

In addition to these kinds of stones, basalt (black stone), a third kind, is available in the

3 ZIARA, 1995: 13

4 RAgEtTE, 2012: 28
Galilee area. It was used only in this area and can be rarely found elsewhere. There are also a number of decorative stones, such as the Mizzi Akhdar. They are denser, more compact and can be polished. ${ }^{2}$

Mud-bricks - Mud-bricks (sun-dried bricks) were used in the Gaza area and in Jordan valley, especially Jericho. This material was formed in wooden molds after grading. It was used in ancient cultures and found in many areas in Palestine like Gaza and Jericho. Mudbricks were prepared from the local mud (red soil), mixed with sand, existing chemicals in the soil, water and dried in the sun. They were prepared in molds usually $20 \times 20 \times 40 \mathrm{~cm}$ to form a block that was used in the building structure (row of blocks). ${ }^{3}$

Mortars - Mortars used for different functions not only require different specifications and preparations, but also are often applied using different tools and techniques. Mortars are composed of two distinct elements: the binder (lime, hydraulic lime) and the aggregates (sand, gravel, brick dust, ashes, straw or other organic elements). The composed materials used for plastering are usually brought from the surrounding villages, where the main plastering materials are made; they are lime and ash, which are a result of burnt wood. They are mixed with additional materials depending on where they will be used. Plastering was used in covering the walls from the inside at a thickness reaching $2 \mathrm{~cm}$ in the middle and sometimes from the outside. It is also used in tiling as mortar or livery for insulation of the roof. A mixture of sand or red soil and lime are sought after to cover the built walls of irregular stone, and its effects are shown in the garden walls and some different buildings in Palestine.

- Lime - Quicklime (Calcium Oxide - CaO) made by burning limestone (Calcium Carbonate $-\mathrm{CaCO}_{3}$ ), was slaked by adding water to create hydrated lime (Calcium Hydrate $\mathrm{Ca}(\mathrm{OH})_{2}$ ). Since ancient times gypsum (juss) and lime (jir) have been burnt to obtain binding agents for mortar. Due to its superior plasticity, gypsum has always been used for decorative work, for molding and relief, for castings, and in its pure form as alabaster for carved or pierced panels. Lime is mainly used for its higher water resistance and strength, but also for its brilliant white color, as whitewash or as finishing plaster (nourah) on important buildings. Coloration into bluish or green hues is very common, soothing for the eye and sometimes having spiritual significance. There have always been attempts to improve strength or impermeability by adding special ingredients. The addition of cinders to mortar mixes in general improves strength and water resistance. Where brick burning was common, the cinders from the kilns, called siflani in North Africa, were used as an ingredient for foundations. ${ }^{4}$
WORdS OF ARABIC ORIGIN

RIJEČI ARAPSKOG PODRIJETLA

Arka

عرقة

Dawwaseh

دواسة

Hasire

Hammal

Jir

Ka'kuleh

حصبرة دوانة

حمال جيز

Maqaed

جير

Khashab ard

Malaki

Mizzi Akhdar

Mizzi Ahmar

Mizi Hilu

Mizzi Yahudi

Nari

Nourah

Qantara

Qas‘a

Rasiyeh

Reash

Shasheyyeh

Shamah

Somaah

Tabun

Taqah

Tawshihah

Trāb

Zifr

كعكولة

مقاعد
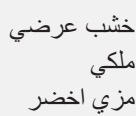

مزي احمر مزي الحمر

مزي حلو

مزي يهودي

ناري

نوره

قنطرة

كساء

راسية

رياش

شاشية

شمعة

صومعة

طابون

توشيحة

تر اب

زفر 


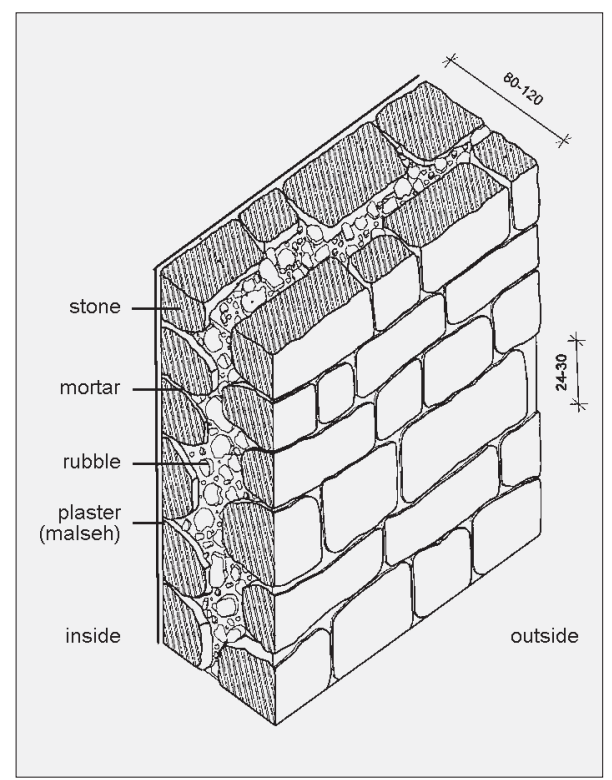

FIG. 2 AXONOMETRIC PREVIEW: A WALL WITH INTERIOR AND EXTERIOR STONE CLADDING

SL. 2. AKSONOMETRIJSKI PRIKAZ ZIDA OBLOŻENOG KAMENOM S VANJSKE I UNUTRAŠNJE STRANE

Fig. 3 SECTION SHOWING THE FOUNDATION OF WALLS AT THE LOWER PART

SL. 3. PRESJEK TEMELJA ZIDOVA NA NIŻEM DIJELU

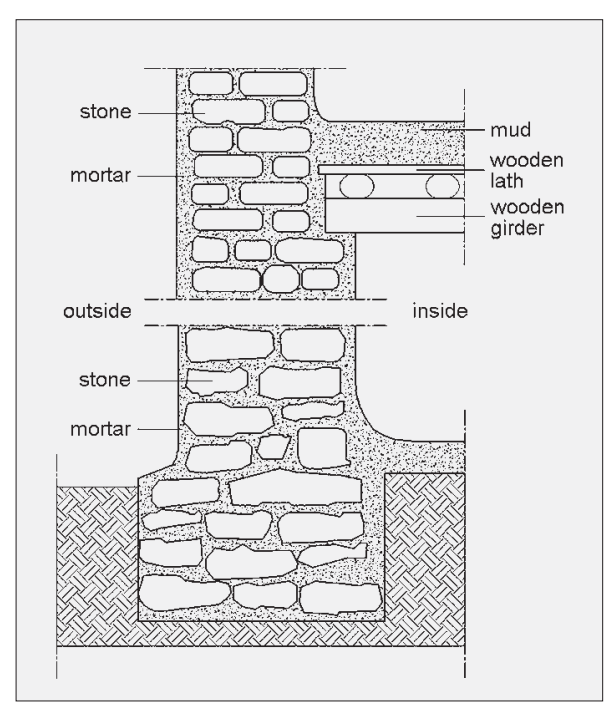

- Sand - Sand gives mortar most of its characteristic color and texture. In traditional buildings, sand was not screened and graded as today and had therefore different size of grains. Natural sand is much better than manufactured one for binding with lime. Other aggregates like brick-dust usually make up a small proportion of the total. Other materials like animal hair, clay particles and partially burnt lime are commonly found in old mortars. ${ }^{5}$

Wood - In general, wood is not only scarce in the Arab Region. Traditionally, wood is precious, and every bit of it has to be used judiciously. The option is either few big beams, or many thin beams. Superimposed systems of principal beams or girders spanning from wall, plus secondary beams across the girders, plus ribs or matting from beam to beam serve as support for the mud roofing houses in Jordan valley and the coastal plain. Small sized wood is cleverly used for doors, paneling, grills, shutters and small furniture. Intricate joinery makes for decorative effect and accommodates the effects of changes in humidity.

Concrete hollow blocks with external plaster - This type is mainly found in Gaza Strip, Jordan valley, refugee camp and villages. Hollow blocks are cheaper than stone, this type of walls can reduce the total cost up to $50 \%{ }^{6}$ Such type of walls are made of one layer of hollow blocks with external and internal plaster and paintings, or with two layers, with insulation. The efficiency of this wall is less than the stonewalls, humidity and salt layers can be found on walls in Gaza strip area, and the plaster needs maintenance every now and then, depending on the orientation of the elevations and the exposure to the salty wind coming from the sea.

\section{Traditional Construction Detalls}

\section{TRADICIJSKI DETALJI GRADENJA}

The master of the house, lacking any training in architecture, has nevertheless gathered from experience much practical knowledge, used to plan and to execute the house, from the first stone until the work ends. In addition, the inhabitants themselves, used to help building their own houses. ${ }^{7}$ Building Techniques in Palestine are influenced by the materials available domestically, as well as techniques in neighboring countries. In general, there are four main kinds of building materials, which are widely available in Palestine. These are mud or adobe; concrete, concrete block and cut stone. These kinds of building materials can be used individually or combined to form the structure of buildings. At the beginning of this century and in many villages, mud or adobe were used to construct houses. In many cases, houses were constructed with dry stone and plastered roughly on the outside with mixture of mud and ashes. The roof was sometimes constructed from branches or brushwood covered with mud. It described the way in which the roof was constructed in many Palestinian cities.

In the following paragraphs, the traditional construction methods of the main structural elements will be briefly described, to give the general background of these discarded construction methods. The construction methods are of great importance as a part of the Palestinian heritage and culture. For that reason, they must be revived, if not used in modern construction, then at least to learn how to preserve the existing structures. (Fig. 1).

Foundations - The master of the house, marks the course of the foundation, which is dug by hired work or by the owner's relatives. The excavation continues until a sound startum is reached. Occasionally, the trenches are five to ten feet deep. When the solid rock is exceptionally deep and it is too expensive and dangerous to dig down to it, the trenches are dug as deep as the proposed height of the house. In those cases, a firm and a hard layer of earth is chosen for the foundation courses. The lower courses are made broader than those built on the solid rock. ${ }^{8}$

Another method is to dig at distance of two or three-meter large square holes, two metre square, all along the foundation lines. In these holes, thick strong piers (Somaah, pl. Somaat) are built. They are joined by strong and board arches built of lat (large flat slabs of the hard stone). The top of the arches should not rise, as a rule, higher than the level of the ground. The foundation construction is built of rubble stone and mortar. The breadth of this wall must be $20-40 \mathrm{~cm}$ more than that of the house wall, and as a rule not less than $120 \mathrm{~cm} .{ }^{9}$ (Fig. 3)

Walls - In the traditional Palestinian construction, there are two basic types of walls: walls made of stone and walls made of mud, used in two different regions.

- Stone walls - Stones that are used for building in Palestine and on a large scale can be divided into two types: two linked facing and one facing.

Two linked facing wall - This type of wall is used for all types of buildings. These walls are constructed after digging and making the foundation system. These walls exist even for the internal division walls. In particular cases, the walls were built directly on the clear rock layer with no real earth works. Furthermore, this type of walls is associated with 
continuous foundation system, which is usually made of thicker walls of bigger two linked rough stone faces with mortar, earth and gravel fill. In particular cases, when the walls were built on the clear rock layer, no foundation system was needed. Stone were used as the construction materials. Stone hardness varies depending on the stone origin and the depth of stone strata, the thickness of wall depends on the height of the building as well as on the type of floor used. The thickness of the wall gets thinner as we get higher. Furthermore, the texture of the stone might change from floor to other separating different types, by one stone course as a simple cornice. Usually when we get higher, the stone texture becomes smoother. Walls of this type have good thermal performance, they serve as good insulator in all extreme weather conditions, because of their thickness and the fact they reflect the sun heat through their light colors. This technique allows column construction, these columns can be made of stone pieces put together with minimum mortar on top of each other, or they can be cavity walls, as in walls, filled by mortar and gravel. Furthermore, the use of stone column in the classical way (one long piece) was the other possibility to construct the columns of arcades or verandas. This way of column construction existed in Palestine in the Roman period; it was widely used in private and public buildings. Regular pointed stonewall is the most used technique in traditional architecture in all types of buildings such as monuments, tombs, stables, stone mashrabiyyas, madras's (schools) and even in stone walls in gardens. The materials used in the construction (stone, mortar and gravel fill, the type of the stone used and its physical characteristics) are important to resist the weather conditions and deterioration problems. Excessive cost of stone, the appearance of new materials and techniques in addition to the lack of the skilled-trained masonry builders caused the disappearing of this technique and accelerating the use of new materials, which are less expensive and easier to work with and plaster. ${ }^{10}$ (Fig. 2)

One facing wall - This type of wall exists in the mountain rural areas. It is associated with continuous foundation system, which is usually made of thicker walls of bigger two linked rough stone faces with mortar, earth and gravel fill. The building materials used

\footnotetext{
5 BADAWI, 2014: 5

6 BenNy, 1995 (Depends on: BADAWI, 2014: 4)

7 CANAAN, 1933 (Depends on: QAMHIEH, 1992: 128)

8 QAMHIEH, 1992: 114-115

9 CANAAN, 1933: 26

$10 * * * 2002: 7-8$

$11 * \star \star 2002: 8-10$
}

for this type are stone, mortar, gravel fill; limestone and stone rubble of different sizes were put either in the foundations or in the internal part of the wall. The thickness of stone ranges from $20 \mathrm{~cm}$ to $35 \mathrm{~cm}$. Walls of this type have good thermal performance; they serve as good insulator in all weather conditions, because of their light materials and sun heat reflection through their light colors. Furthermore, this type has good acoustic performance, they serve as good insulator from outside effects due to their thickness, and they absorb the echo inside due to the plasters high porosity. The one facing wall is rarely found. It is used in rural areas to construct Saqeefeh (Peasant house), storage places, and cattle place. The type of the stone used and its physical characteristics are important to resist the weather conditions and deterioration problems. For example, the soft limestone of bad quality will deteriorate quickly and lead to demolition of the wall. The quality of the mortar used as a linking material of the two faces of the wall is very important to keep these two faces together, if this mortar had been loose or of bad quality with little binding materials, this probably would have led to the demolition of the wall. ${ }^{11}$ (Fig. 4)

There is another type of walls, a Stone laid dry (Rubble Masonry). This type of wall exists in the mountain areas. This technique originates from the last two centuries and it is still used in barrier construction in rural areas. The building materials used for this type are stone, limestone and rubbles. The thickness of the walls depends on the size of the span of the structure or the height of the structure whether it is a farmhouse or a retaining wall in the landscape. The wall was not intended to be protected, while the roof for farmhouse structures was intended to be covered with slightly rough earth layer mixed with little lime mortar, with a clear slope for rainwater drainage. This type of wall was used to build farmhouses, stables, retaining walls and barriers in landscape. (Fig. 5)

- Mud-Brick Walls - This type of wall is associated with simple stone continuous foundation system. This type of wall is used for all types of buildings such as housing, commercial, farmhouses, convents and monasteries. The material used in production is sun-dried clay, which is not hard. This technique is very old, this type of walls was built in Jericho city and one of the most known refugee camps called Ein El-Sultan camp in the Jordan valley was built with mud-bricks in 1950s. Walls of this type have good thermal performance, since they are of light material; they serve as good insulator in extreme weather conditions. Mud walls are to be permanently maintained, since material used in construction is

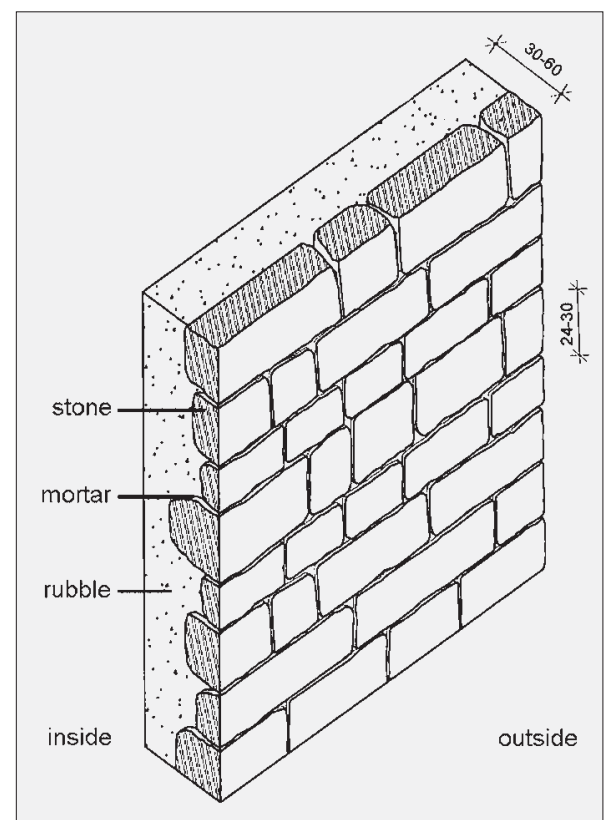

FIG. 4 AXONOMETRIC PREVIEW: A WALL WITH EXTERIOR STONE CLADDING

SL. 4. AKSONOMETRIJSKI PRIKAZ ZIDA OBLOŻENOG KAMENOM S VANJSKE STRANE

FIG. 5 HOUSE WITH STONE CLADDING JERIES EL-AJLOUNI IN RAMALLAH, 1914

SL. 5. KUCA OBLOŻENA KAMENOM S VANJSKE STRANE JERIES EL-AJLOUNI U RAMALLI, 1914

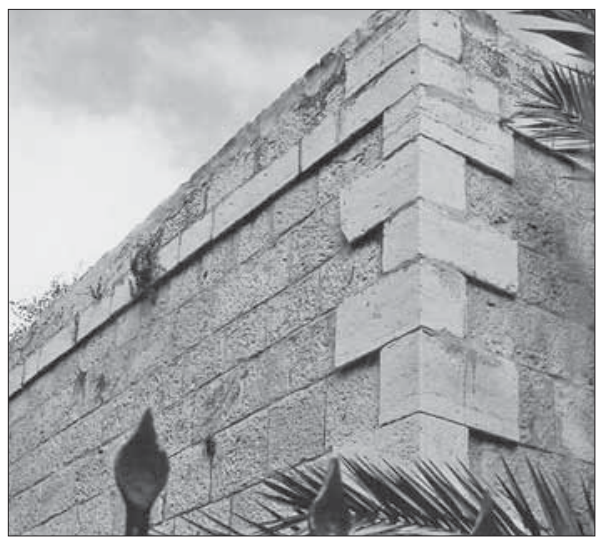




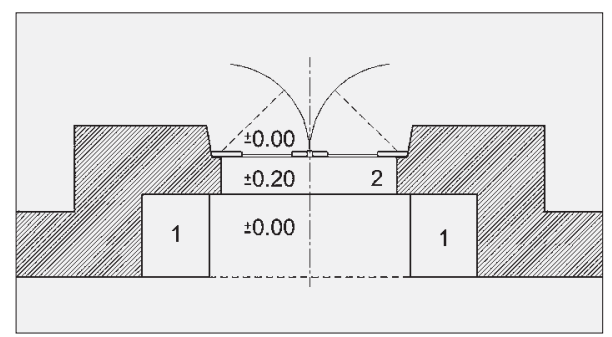

FIG. 6 DETAILED TRADITIONAL DOOR SL. 6. DETALJ TRADICIJSKIH VRATA

FIG. 7 AXONOMETRIC PREVIEW OF A TRADITIONAL PALESTINIAN DOOR: 1 - STONE SEATS (MAQAED); 2 - THRESHOLD (DAWWASEH); 3 - LINTEL (SHASHEYYEH); 4-SPRINGER (HAMMAL)

SL. 7. AKSONOMETRIJSKI PRIKAZ TRADICIJSKIH PALESTINSKIH VRATA: 1 - KAMENA SJEDIŠTA (MAQAED); 2 - PRAG (DAWWASEH); 3 - NADVOJ (SHASHEYYEH); 4 - PRVI (POCETNI) KLINASTI KAMEN LUKA (HAMMAL)

FIG. 8 EXAMPLE OF APPLICATION OF CLAY BRICK IN THE PALESTINIAN ARCHITECTURE

SL. 8. PRIMJENA GLINENE OPEKE U PALESTINSKOJ ARHITEKTURI

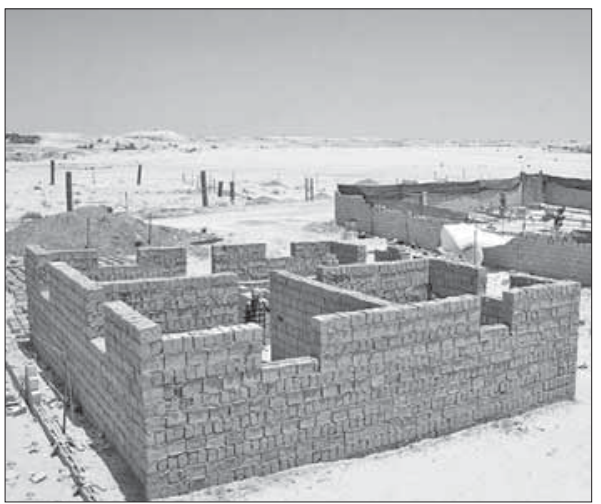

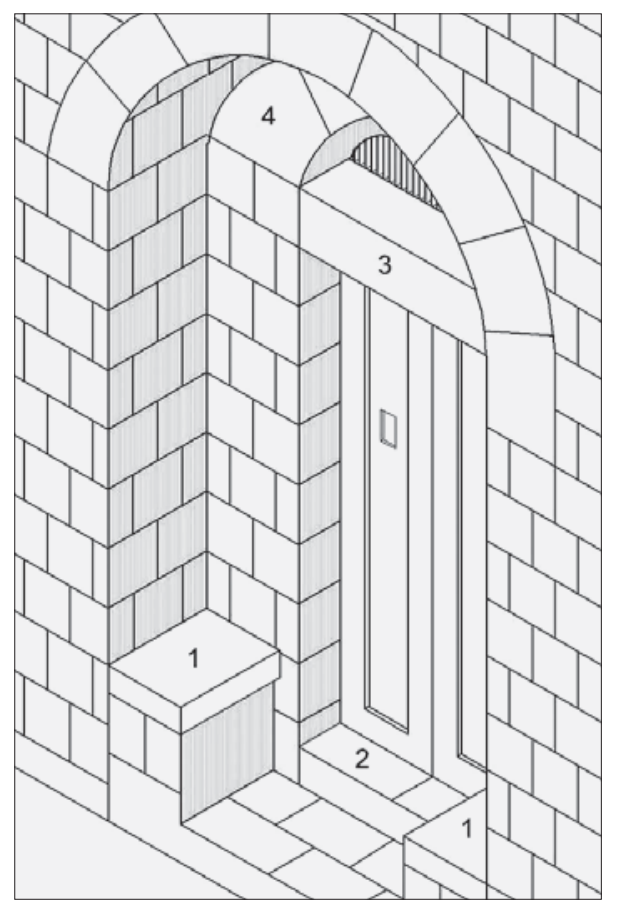

very light and not resistible for the outside natural changes such as sun, water and veg. etation. Those usually cause cracks in the plaster allowing water to penetrate, which causes weakness in structure by flushing out the mortar thus causing the mortar falling out. ${ }^{12}$ In addition, the structure, which is associated with this type of walls, is usually made of assembled wood structure with mud roofing on the top of it. Once this mud is not protected and painted by plaster, rainwater penetrates from the upper side of the wall, causing direct destruction of the joints and the mortar, which keep the blocks together. Then the wall collapses, as it is not resisting the loads any more. The appearance of new materials and techniques, which the average people considered a symbol of the modernity and civilization, led to the absence of this technique in contemporary buildings. At the same time, this kind of wall is still used in the construction, but in a much smaller scale, one can still see that technique used in oven (Tabun) construction in rural areas and in the restoration works of the exciting mud structures. (Fig. 8)

The Openings - The main characteristic of a traditional Palestinian house is the main entrance door in the houses and the palaces that have a semicircle form. It usually contains transcriptions from the Koran or other poetic texts from the traditional Palestinian literature, inscribed with decorative colors inspired by the different vegetations in Palestine. The main entrance doors are made of decorative wood, in different geometric forms and shapes. However, nowadays these doors are changed by the use of the metal ones.

The openings in the traditional architecture are the most significant elements, reading the opening in some cases can tell the estimate year of the building and the type of use. In villages and peasant houses they had few or no windows (for security reasons); they were small and set high up in the wall. By time they got larger and were placed lower down. The doors are set in the middle of the façade in most cases, they are lower than the human body and by time they got larger and wider. In cities and towns openings were larger and wider and they were set in a lower position in walls. The wood was used in both doors and windows as the shutter materials, and the glass was later used to let light in buildings.

Some openings were made in walls by pottery, these small openings in walls created a privacy to the inner side of the wall. The openings were made to let the fresh air pass inside the open space (usually). These kinds of openings were used in some villages and cities like Jerusalem and Bethlehem. There is a probable link between the introduction of glass as a membrane material and the width of openings: until the $1850 \mathrm{~s}$, glass was not common in windows in Palestine. Windows were merely openings usually not exceeding one meter wide. ${ }^{13}$ (Figs. 6-7)

The windows were mainly oriented towards the interior yard of the house regarding the privacy of the inhabitants especially at the ground floor. At the first floor, these windows were very practical for better lightening of the space.

The shapes of the windows in Palestine were mainly double window or a triple one that contained an extraordinary architectural shape of the facade, and occasionally with small openings above the main entrance doors which were practical for ventilation of the building. (Figs. 9-10)

\section{ROOFING}

\section{KROVIŠTA}

Traditional roofing systems differ from one place to another according to the type, size and use of the building. They can be categorized into four groups: flat roofing, pitched roofs, domes and vaults.

Flat roofing - Flat roofs existed in many forms according to their building materials, which varied from mud to stone tiles. Mud roofing exists in the mountain rural areas. The mud roofing was associated with buildings of different types, mainly, the residential 


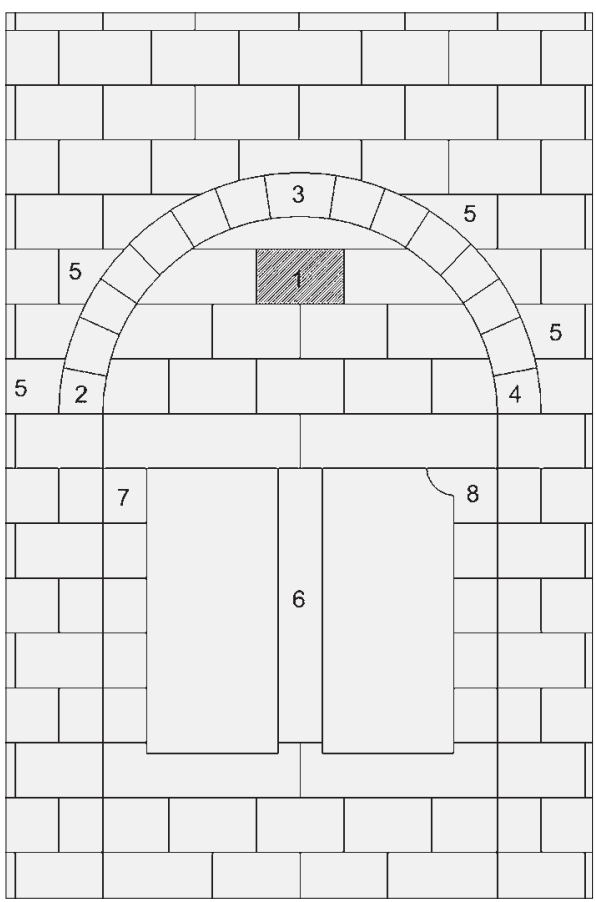

houses, stables, and agricultural storages. In most cases, the mud walls were associated with wooden roof structure and mud insulation. The mud roofing was associated with frame superstructure manly appeared in the Ottoman period especially in the $17^{\text {th }}$ century and continued to be used until the late 1940 .

Mud is the most basic building material. With experimentation and experience, the best combination of sand, loam, clay, silt and water has resulted in similar mud construction. Clay properly mixed with water becomes a cohesive and plastic mass, capable of taking any shape. When dried in the sun it will gain surprising strength; and if the units are small enough they will not develop shrinkage cracks. If again subjected to water for limited time, such as a day of rain, the moisture will penetrate for a few millimeters, after which the clay pores will close and further water will run off. In the case of erosion, force of running water - such as at downspouts, or permanent water attack, superficial shrinking cracks form. These need to be closed immediately, while the surface is still plastic, or they should be patched up before the next rain.

Otherwise, the next rainfall will penetrate much deeper and cause serious deterioration. This is why mud structures can be long lasting if rainfall is very rare (Egypt, Arabia),

\footnotetext{
12 Aвu AJWA, 2011: 32-33

13 SCHICK, 1897: 106 (Depends on: GoLdMAN, 2003: 131) RAGETTE, 2012: 24
}

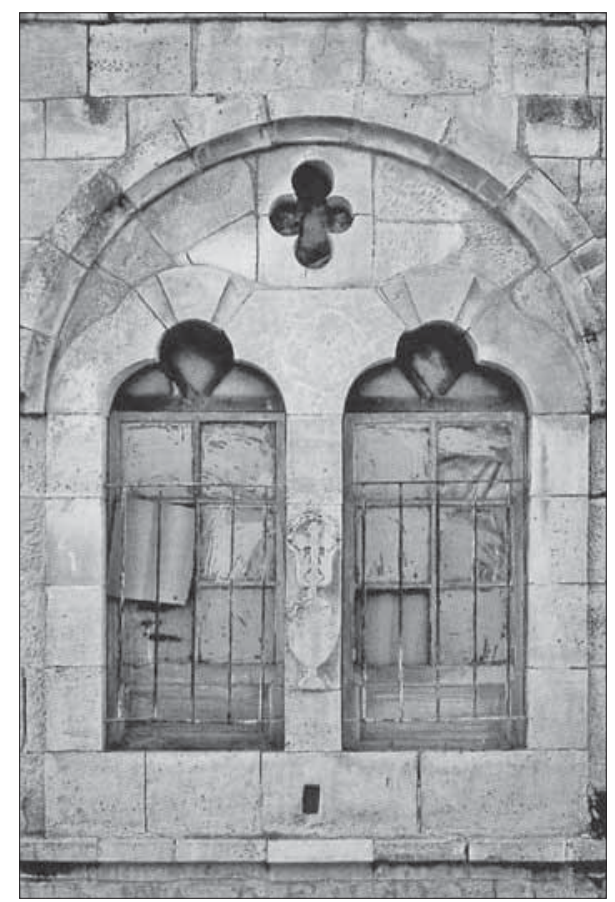

Fig. 9 SCHEMATIC SKETCH OF A DOUBLE WINDOW: 1 - OPENING FOR VENTILATION (TAQAH); 2-4 - SPRINGERS (HAMMAL); 5 - SIDE STONE (TAWSHIHAH); 6-PILLAR (SHAMAH); 7 - STONE (RASIYEH); 8 - STONE (ZIFR) SL. 9. SHEMATSKA SKICA DVOSTRUKOG PROZORA: 1 - OTVOR ZA VENTILACIJU (TAQAH); 2-4 - PRVI (POČETNI) KLINASTI KAMEN LUKA; 5 - BOCNNI KAMEN (TAWSHIHAH); 6 - POTPORANJ (SHAMAH); 7 - KAMEN (RASIYEH); 8- KAMEN (ZIFR)

FIg. 10 Double WINDOW OF THE HOUSE AL-AJLOUNI IN RAMALLAH

SL. 10. DVA PRozora KuCE Al-AJlouni u RAMALLI or if they are maintained properly (Palestine, Syria). ${ }^{14}$

The mud roofing is about 10 to $15 \mathrm{~cm}$ thick, not including the frame thickness that depends on the span and the wood quality. The building method used in this type of roofing is mixed with vegetal bond stacked with branches and leaves on a wood trunk frame. This type of roofing is suitable to resist all extreme weather conditions (wind, rain, snow) in Palestine, especially in the Jordan valley area, which is very dry. However, in rural areas in the middle of mountains, the mud roofing is maintained in regular bases and its quality is enhanced by adding the lime to its mortar. This type of roofing shows positive thermal performance, it acts as good insulator from outside effects and it serves as good insulating material with light components. In addition, on the level of expansion and extraction it is suitable for the weather conditions.

Stone tiles roofing was used in all types of buildings, the technique is still used, but in regular shapes with concrete mortar for different types of buildings especially houses. The technique is still alive in contemporary structures with little changes, the stone tiles are mechanically cut and of regular dimension, while the traditional ones are irregular with different dimensions. The mortar used nowadays is a cement mortar, while the traditional one is a lime mortar.

Flat roofs played an important part in daily life in Arab villages as well and towns. These were used to dry fruits and vegetables, age 

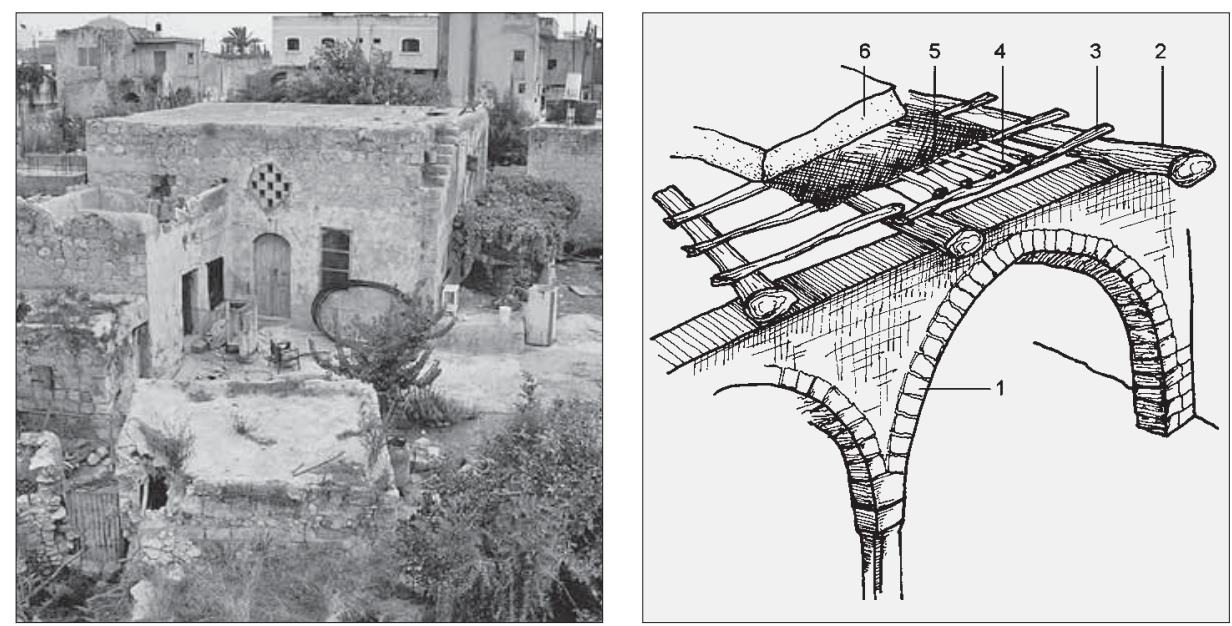

Fig. 11 Flat Roofing in house Said Abu Hamdeh IN ZEITA NEAR TULKARM

SL. 11. RAVNo KROVIŠTE KUĆE SAID ABU HAMDEH U ZEITI BLIZU TULKARMA

Fig. 12 PreVIeW of FLAT Roofing SYStem: 1 - TRANSVERSE ARCH (QANTARA); 2 - TIMBER BEAM (ARKA); 3 - TIMBER CROSS BEAM (KHASHAB ARDI); 4 - REEDS OR BRANCHES (QAS'A); 5 - THORNY SHRUBS (HASIRE) IN MOIST EARTH; 6-20-25 CM THICK EARTH LAYER (TRĀB) AND CHAFF, WITH LIME USED AS A FINISHING

SL. 12. PRIKAZ RAVNOG KROVIŠTA: 1 - POPREČNI LUK (QANTARA); 2 - DRVENA GREDA (ARKA); 3 - DRVENA POPRECNA GREDA (KHASHAB ARDI); 4 - TRSKA ILI GRANE (QAS'A); 5 - BODLJIKAVO GRMLJE (HASIRE) U VLAŽNOJ ZEMLJI; 6 - 20-25 CM DEBELI SLOJ ZEMLJE (TRĀB) I SLAME, S VAPNOM KAO ZAVRŚNIM SLOJEM

Fig. 13 House Khalil Salah in Ramallah, 1926 SL. 13. KuĆa KHALIL SALAH U RAMALI, 1926.

FIg. 14 AXONOMETRIC PREVIEW OF PITCHED ROOF ROOFING SYSTEM

SL. 14. AKSONOMETRIJSKI PRIKAZ KOSOG KROVA

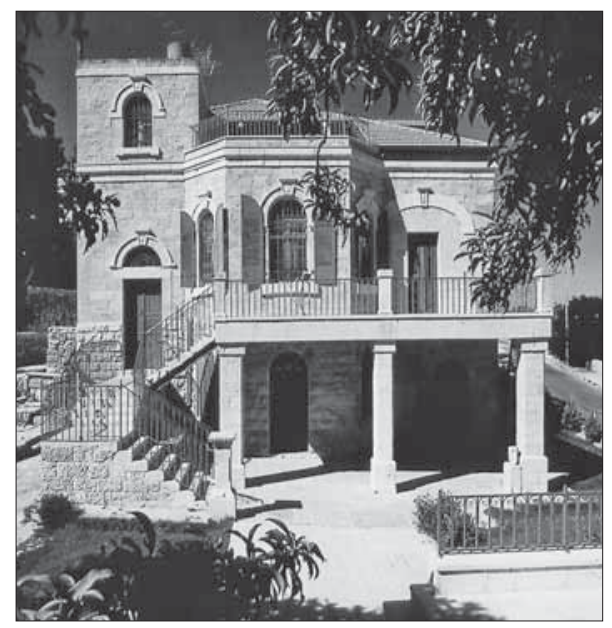

touched upon the urban populace, but did not reach the villages. ${ }^{17}$ (Figs. 13-14)

Domes - The domes were used in rich houses or in important public or religious buildings such as mosques, tombs, khans, caravanserai and madras's (schools). This technique is a very old one, dating back to Byzantine times in the $5^{\text {th }}$ century. This technique disappeared because of the excessive costs and lack of materials and the skilled workers to do the work. The creation of the new building concepts using concrete made it easier and quicker to construct bigger and higher buildings or domes.

Stone and limestone, pebbles, lime and rubbles are the construction material used for domes; all the materials can be found in the market in the traditional or industrial form. Mortar was used as the building method in domes, as in the cross vault, where the work needed a framework. Usually the framework was made of wooden structure or by earth fill with branches and leaves cover in the form of a dome, which was removed from the doors after the construction of the dome. The frame was intended to be protected; it was plastered from the inside and covered by stone tiles or lime plaster from outside. The dome was mostly intended to be protected by lime plaster. In some cases, the dome was left as it was, especially when the stones were well cut and decorated such as in tombs and madras's of Mamlouk architecture. 5 meters is a possible spanning structure with this type of frame. In this case, the frame is of $30-50 \mathrm{~cm}$. There are no specific methods to increase the span, but the thickness of the walls and the frame make it possible to increase the span (the thicker the walls and the frame the longer span one gets). (Fig. 17)

As in the case of the vaults, the frame of these types shows positive thermal performances, it serves as a good insulator from outside effects. On the level of expansion and extraction, the frame is suitable for the weather conditions. The shape of the stones applied in the dome should be segments of $3 \mathrm{D}$ sphere to achieve maximum surface of loading. This implies the hard work of the stone carver, especially when the stones of the dome are meant to be seen from beneath, then every piece, should be cut in proper and accurate way giving it a number and a direction. The stone deterioration of the dome frame, the stone tiles and joints deterioration, the cracks in the frame plaster and the vegetation growth lead to major cracks and failure of the frame. ${ }^{18}$ (Figs. 15-16)

\footnotetext{
15 KROYANKER, 1985: 43

16 SALAMEH, 2012: 39

17 AVITSUR, 1976: 263 (Depends on: GoldMAN, 2003: 128)
} 


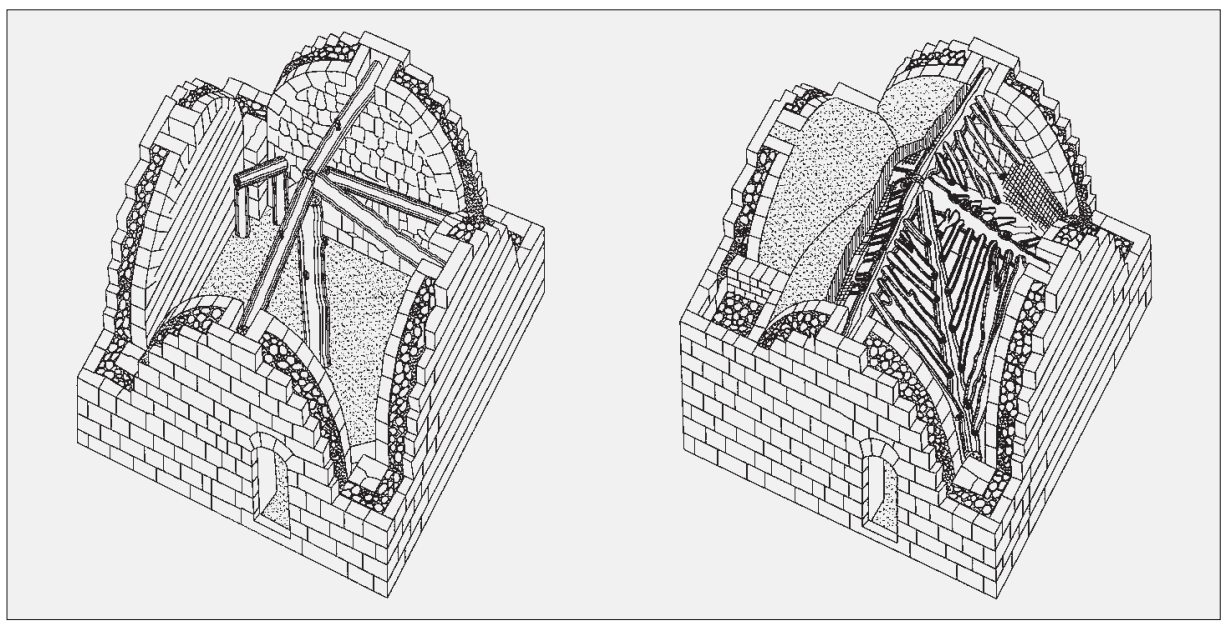

Vaults - Vaults are one of the oldest construction techniques in Palestine for building roofs since they depend on their shape to transmit loads from the roof through walls to the foundations and then to the earth. Vaults existed in Palestine in two shapes, barrel vaults and cross vaults.

- Barrel vaults - The barrel or tunnel vault if supported by walls results in a tunnel-like space. Support walls must be heavy to assure buttressing. Illumination through the vault is difficult and is best achieved from the end of the tunnel. Barrel vaults are usually built using framework either stacked wood, or earth fill using branches or leaves that form the shape of the barrel vault. After constructing the vault, the earth fills are removed. Palestinians used two types of barrel vaults: pointed and semicircular. Building materials for barrel vaults consisted of earth, stones, pebble, lime and branches of trees. Barrel vaults are usually used for large-scale buildings; the way of building barrel vaults depends on the special stone pieces called (Reash) and the mortar. Barrel vaults are mostly used to cover building of rectangular shape plans; the direction of the vault goes with the long sides. ${ }^{19}$ (Figs. 18, 19 and 22)

- Cross vaults - Cross and keyed vaults were used for all type of buildings: public, commercial, or residential. Mortar was used in the building method, the construction materials used for this type of frame were earth, stone, limestone and lime and rubbles. As in the case of stone walls, the frame of these types has positive thermal performance, it serves as a good insulator against outside influences. In Palestine, we find a unique system of masonry cross vaults with mud cover constructed over center-supported wood formwork. It gener-

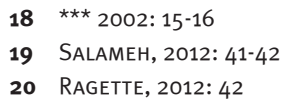

ates characteristic domical square spaces. More often, such groin vaults were executed in stone, slightly parabolic in section. They provided the standard unit of construction in Palestine. In other parts of the Arab Region vaulting was reserved either for important spaces, such as reception halls in palaces, parts of mosques, tombs, or for basements and storage rooms. ${ }^{20}$ (Figs. 20-21)

\section{CONCLUSION}

\section{ZAKLJUČAK}

Traditional building methods in Palestine are of great importance for the history of architecture in general, and for the Palestinian architecture in particular. The simplicity and local building materials for these houses help us in formulating a modern understanding of the nature of emptiness, space, the environment, and the history, which were reflected in the different architectural shapes and styles in Palestine.

Architectural simplicity is a complex beauty resulting from the interaction of different com-

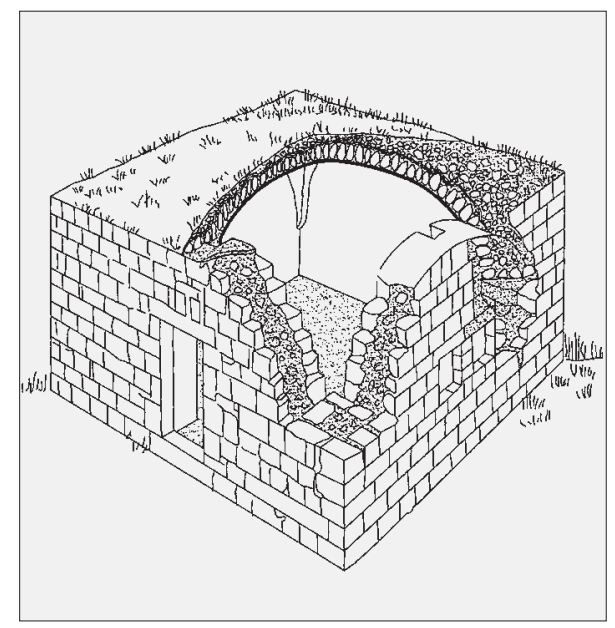

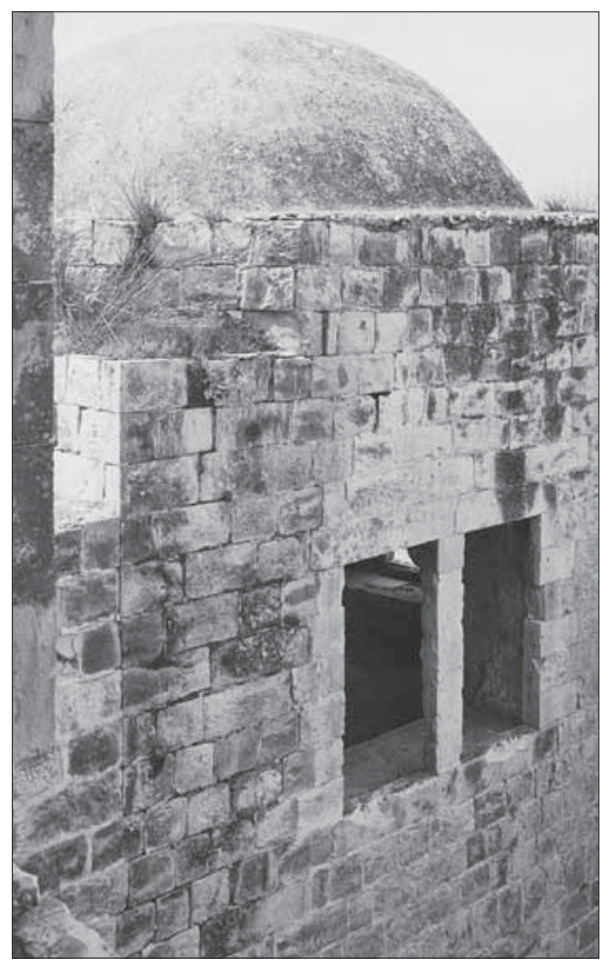

FIG. 15 THE ESTABLISHED DOMES IN TRADITIONAL BUILDINGS SL. 15. KUPOLE U TRADICIJSKIM GRADEVINAMA

Fig. 16 Dome in Palace Al-QAsem in Beit Wazan SL. 16. Kupola na PalaĆ Al-QASEm u Beit Wazanu

FIG. 17 AXONOMETRIC PREVIEW: DOME IN TRADITIONAL BUILDINGS

SL. 17. AKSONOMETRIJSKI PRIKAZ KUPOLE U TRADICIJSKIM GRADEVINAMA 

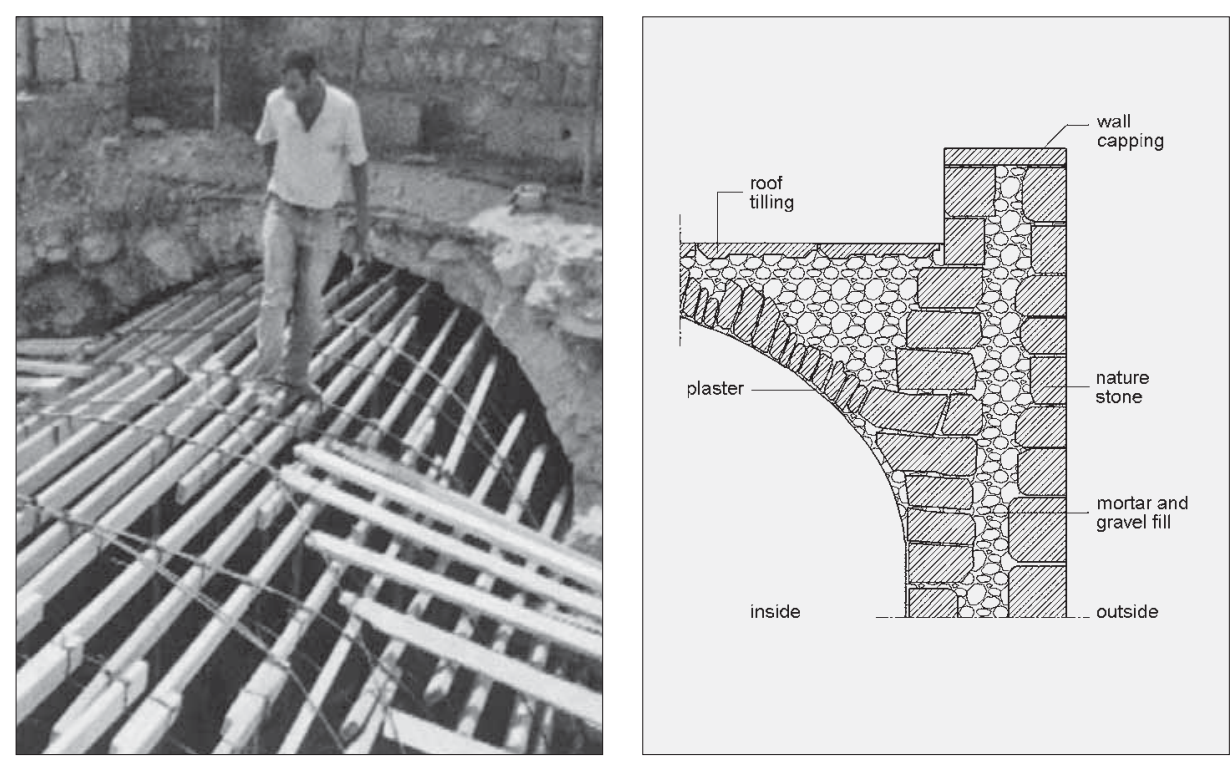

Fig. 18 Barrel Vaults in Saer near Hebron SL. 18. Baćvasti SVOdovi u SAERu blizU Hebrona

Fig. 19 SECTION SHOWS THE BARREL VAULT ROOFING SYSTEM

SL. 19. PRESJEK BAČVASTOG SVOdA KROVIŠTA

Fig. 20 Cross Vaults NeAR PALACE IN VILLAge Araba SL. 20. KRIŻNI SVODOVI BLIZU PALAČE U SELU ARABA

FIG. 21 AXONOMETRIC PREVIEW OF CROSS VAULT ROOFING SYSTEM

SL. 21. AKSONOMETRIJSKI PRIKAZ KRIŽNOG SVODA KROVIŚTA

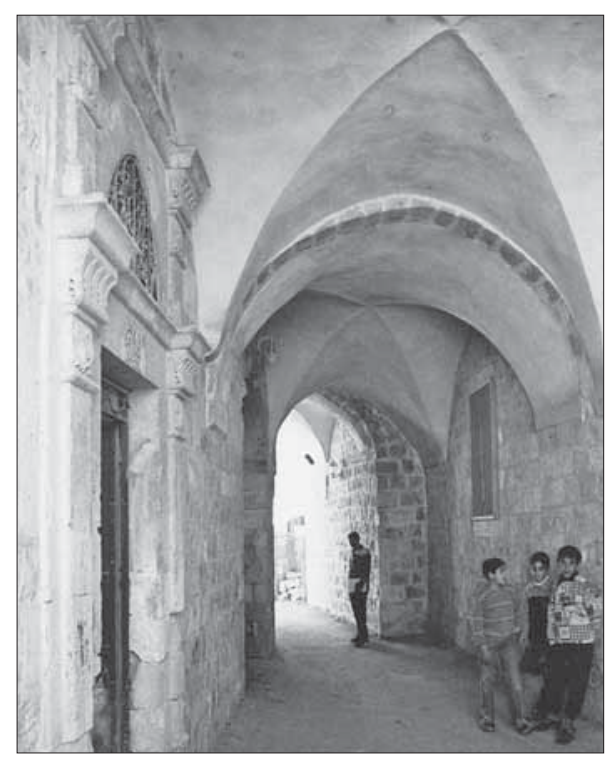

disappearance, because of the difficult conditions experienced by the Palestinians. It provides a profound insight for smart architectural building methods that can affect and inspire us to build a better space and better future.

Traditional building methods in Palestine allow us to ask general questions about architecture: questions about the nature of the place, the community, their ways of life and continuity, and the role of the Palestinian women in the maintenance of these buildings. The buildings constantly needed layers of mud plastering and limestone painting and tenor layers of the surfaces in order to reach our present time. There are other challenging questions about the spatial complexity of a simple cube and sensual questions through visual movement provoked by the buildings few openings and the small openings above the doors and elsewhere. There is no doubt that the traditional construction methods in Palestine are an extension of the architecture surrounding Palestine and its regions, whether from the neighboring countries, or the broader geographical depth, which is represented by the Mediterranean Basin. This geographical and cultural communication between these regions, and its presence within similar circumstances, in particular the ways of life and habits, and more important the local building materials, in addition to their participation in a similar climatic and geological nature, calls for an architectural similarity to a far extent in the construction methods and the local building materials. This shows that architecture is an expression of interstitial social, economic, and cultural needs, and it has symbols beyond physical infrastructure and architectural compositions of these houses. The presence of such patterns in many regions of the Mediterranean Basin can be historically interpreted as an extension of very old building traditions. For example, in Palestine, specifically in the city of Jericho, the late Stone Age (8000-1000 B.C.), is characterized with the presence of circular houses roofed with wood, as with most of the house that were underground. Moreover, complex composition houses appeared that were roofed with wood around ( 3200 B.C.) as it is in the city of Beit She'an, and the archeological city of Tel Al-Fara, north of the city of Nablus. The continuity of these patterns for a long and extended period shows the symbolic dimension of these houses that make up the formations and building materials used in the backbone of the social and economic life in Palestine.

Traditional structures vary in shape and building techniques: they almost share similar sustainable properties such as the use of local material, being environmentally friendly, and maintaining a suitable environment inside the building. 
Moreover, ancient people were very intelligent in developing their techniques, which were established to fit the sustainable requirements. Nowadays, they become less efficient due to raising cost of implementation, absence of skilled workers and the emergence of contemporary building materials and techniques.

Today there are many buildings in Palestine that expose the traditional use of constructions made of stone that express the historical and cultural meaning, as well as the geographical and climate conditions in this area as an important fact that greatly emphasizes the architectural expression as it is.

Palestinian architecture and the Palestinian way of construction deserve a special attention because this architecture is greatly threatened to be lost in the near future. This special kind of construction should be greatly elaborated, it is a theme for open discussion, deeper investigation, and a challenge for other technicians and architects.

[Translated by author]

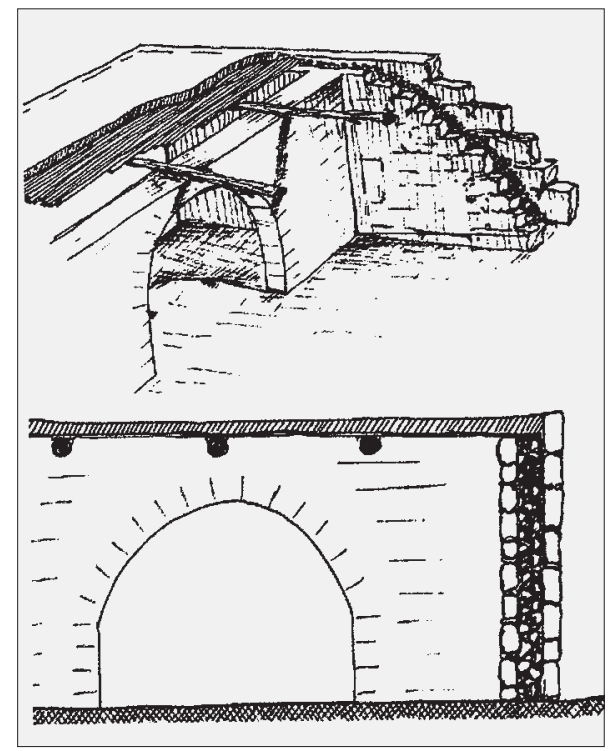

Fig. 22 Section ANd AXonometric PREVIEW OF BARREL VAULT ROOFING SYSTEM

SL. 22. PRESJEK I AKSONOMETRIJSKI PRIKAZ BAČVASTOG SVODA KROVIŚTA 


\section{BIBLIOGRAPHY}

LITERATURA

\section{SOURCES}

|ZVORI
1. Aвu AJwA, E.H. (2011), Mud Building Practices in Construction Projects in the Gaza Strip, The Islamic University - Gaza, Faculty of Engineering, Civil Engineering Department, Gaza, Palestine

2. Al-Jubeh, N.; Bshara, K. (2002), Ramallah Architectural and History, Riwaq Centre for Architectural Conservation \& Institute of Jerusalem Studies, RIWAQ's Monograph Series on the Architectural History of Palestine 14, Ramallah [Arabic]

3. AmIRY, S. (2003), Throne Village Architecture Palestinian Rural Mansions in the Eighteenth and Nineteenth Centuries, Riwaq Centre for Architectural Conservation \& Institute of Jerusalem Studies, RIWAQ's Monograph Series on the Architectural History of Palestine 7, Ramallah [Arabic]

4. AmIRY, S.; JAN, C. (1987), Das palaestinensische Haus, in: VoeLGER, G.; WeLCK, K.V.; HACKSTEIN, K. [eds.]. Pracht und Geheimnis-Kleidung und Schmuck aus Palästina und Jordanien, Pp. 9298, Koeln

5. Amiry, S.; TAMARI, V. (1989), The Palestinian Village Home, Published for the Trustees of the British Museum by British Museum Publications Republished by Riwaq, London

6. AwAD, J. (2012), Houses of Rural Palestine, Riwaq, RIWAQ's Monograph Series on the Architectural History of Palestine, Ramallah [Arabic]

7. Badawy, U. (2014), A. Climate Conditions Impact on the Architectural Design in Palestine, "European Journal of Academic Essays", 1 (3): 1-7 [www.euroessays.org]

8. Canaan, T. (1933), The Palestinian Arab House, Its Architecture and Folklore, "Journal of the Palestinian Oriental Society", Syrian Orphanage Press, Jerusalem

9. Goldman, D. (2003), The Architecture of the Templers in their Colonies in Eretz-Israel, 18681948, and their Settlements in the United States, 1860-1925, The Union Institute and University, The Graduate College School of Interdisciplinary Arts and Sciences, Cincinnati, Ohio
10. HADID, M. (2002), Architectural Styles Survey in Palestinian Territories, Establishing, Adoption and Implementation of Energy Codes for Building, Palestine

11. HIRSCHFELD, Y. (1995), The Palestinian Dwelling in the Roman-Byzantine Period, Franciscan Printing Press, Jerusalem

12. ISSA, I.; JUDEH, L. (2014), The Manual for the Protection of the Historic Centre of Ramallah, RIWAQ's Monograph Series on the Architectural History of Palestine 1, Ramallah 17, Ramallah [Arabic]

13. JäGER, J. (2012), Describing traditional architecture in rural areas, examples from Syria and Jordan, in: Stone and Architecture in the mountainous regions of Jordan and Syria, Amman - Damascus - Berlin

14. KroyankeR, D. (1985), Jerusalem Architecture Periods and Styles, Arab Buildings Outside the Old City Walls, Jerusalem: Keter [Hebrow]

15. QAmhien, F.K. (1992), Saving the Old Town of Nablus - A Conservation Study, Mackintosh School of Architecture / University of Glasgow, PhD Thesis at the Faculty of Architecture in Glasgow, Ireland

16. Ragette, F. (2012), Traditional Domestic Architecture of the Arab Region, Axel Menges $\mathrm{GmbH}$, American University of Sharjah, U.A.E.

17. Salameh, R.W. (2012), Towards Sustainable Construction Systems of External Walls of Buildings in the West Bank of Palestine, Al-Najah $\mathrm{Na}$ tional University Master Thesis at the Faculty of Graduate Studies, Nablus, Palestine

18. ZIARA, M.M. (1995), Improving Ductility of Structural Concrete Members for Resisting Seismic Loading, Symposium on Effects of Earthquakes on Structures, 3-5 October, Amman, Jordan

19. *** (2002), Estabilishing, Adoption, and Implementation of Energy Codes fo Buildings, Construction Techniques Survery in Palestinians Territories

\section{ILLUSTRATION SOURCES}

IZVORI ILUSTRACIJA

FIG. 1 AMIRY, TAMARI, 1989: 21; Photo: Matson Collection, Library of Congress

FIG. 2, 4,

19, 21 Author

Fig. 3 RAgetTe, 2003: 32

FIG. 5 AL-JUBEH, BSHARA, 2002: 81

FIG. 6, 7, 9 CANAAN, 1933: 34

Fig. 8 www.bbc.In pictures: Gaza's new mud homes

FIG. 10 AL-JUBEH, BSHARA, 2002: 62

FIG. 11 AWAD, 2012: 68

FIG. 12 JÄGER, 2012: 32

Fig. 13 AL-JUBEH, BSHARA, 2002: 136

FIG. 14 ISSA, JUDEH, 2014: 147

FIG. 15 AmIRY, JAN, 1987; Depents on Jihad Awad, 2012: 97

FIG. 16 AMIRY, 2003: 117

FIG. 17 HIRSCHFELD, 1995: 128

FIG. 18 AWAD, 2012: 50

FIG. 20 AMIRY, 2003: 81

FIG. 22 AWAD, 2012: 65 


\section{SUMMARY}

SAŽETAK

\section{TRADICIJSKI GRADEVNI MATERIJALI I NAČINI GRADNJE U PALESTINI}

Na tehnike gradnje u Palestini utječe dostupnost lokalnih materijala, kao i tehnike gradnje u susjednim zemljama. U načelu postoje cetiri glavne vrste građevnih materijala koji su lako dostupni u Palestini. To su blato ili nepečena opeka, beton, betonski blok i rezani kamen. Ovi se materijali koriste zasebno ili u kombinaciji u gradnji kuca. Početkom ovoga stoljeca u mnogim se selima koristilo blato/ zemlja ili nepečena opeka za gradnju. Često su kuce bile građene od kamena i grubo ożbukane izvana mješavinom zemlje i pepela.

Krov se katkad radio od granja ili šiblja pokrivenog blatom. Tako se gradilo u mnogim palestinskim gradovima poput, primjerice, u gradu Jericho gdje je vecina kuca građena s četiri luka koji nose krov. Blato/zemlja i nepečena opeka uglavnom se koriste u mnogim palestinskim područjima za gradnju kuća. Vjeruje se da takve kuce prużaju svojim korisnicima ugodniju unutarnju mikroklimu negoli nove betonske kuce koje se grade u mnogim podruçjima.

Neke od novoizgrađenih betonskih kuca i druge sagrađene od zemljanih opeka u Palestini pokazuju da je unutrašnja temperatura u kucama od zemljanih opeka 5-6 stupnjeva niża od vanjske temperature, dok je u betonskim zgradama unutrašnja temperatura samo $0.51^{\circ} \mathrm{C}$ niża od vanjske. Kuce od zemlje imaju visok toplinski kapacitet u usporedbi s betonskim kucama, a kad se suhe trave pomiješaju sa zemljom kako bi se ojačali zidovi od zemljane opeke, toplinska se svojstva zidova pojačavaju.

Do druge polovice 20. stoljeca u Palestini se gradilo tradicijskim načinom gradnje. Ponajviše je to bila posljedica nedostatka modernih materijala u graditeljstvu, kao što je cement koji se nije koristio sve do kraja Drugoga svjetskog rata. S obzirom na svoj geografski polożaj, Palestina se oslanja prije svega na svoje vlastite prirodne resurse u pogledu građevnih materijala kao što su kamen, zemlja/ blato i drvo.

Oko 50.000 tradicijskih građevina zabilježeno je u Nacionalnom registru gdje je vidljivo da je kamen glavni i najčešce korišten materijal u regiji Zapadne obale te ponegdje u Gazi, dok su u jordanskoj dolini i obalnoj ravnici Gaze dominantni građevni materijali blato/zemlja i kamen. Ovi i drugi građevni materijali utjecali su na tehnike i načine gradnje svih tipova zgrada, kako onih namijenjenih stanovanju tako i sakralnih zdanja, ali i komercijalnih i poljoprivrednih građevina. Načini gradnje $u$ susjednim zemljama utjecali su na načine gradnje i u Palestini.

Korišteni su drevni načini gradnje, kao što su rimski polukružni svod ili kupole u bizantinskom stilu kakve se mogu vidjeti na kucama ili javnim i sakralnim objektima. Načini gradnje koji potječu iz 5. stoljeca, tj. autohtone tradicijske tehnike gradnje u Palestini, nisu dovoljno istraženi niti detaljno valorizirani prije uvođenja recentnih materijala, kao što su beton $i$ cement. $U$ ovome se radu valoriziraju tehnike gradnje i razliciti arhitektonski elementi: temelji, zidovi s otvorima, svodovi, kupole i krovišta. Njihovom analizom nastoji se pokazati kako veličina građevina i izbor materijala utječu na graditeljsku praksu. Posebna se pozornost pridaje tehničkim normama i standardima s opisom osnovnih građevnih materijala i tradicijskih načina gradnje za svaki od arhitektonskih elemenata palestinske tradicijske kuce.

Bez prisutnosti nekog arhitekta buduci vlasnik građevine utvrđuje konture građevine. Uz pomoc placenih radnika ili rođaka postavljaju se temelji i gra- de zidovi. Znanje kojim se pritom koriste nije akademsko već se prenosi iz generacije u generaciju, što ga čini tradicijskim. Tlocrt građevine formira se prema efikasnosti i praktičnosti. Vrstu materijala diktira ekonomičnost i tip građevine, forma građevine i načini gradnje. Izolacijska svojstva, tj. toplinska, akusticna i izolacija od vlage, u velikoj mjeri ovise o ovim materijalima.

U današnje vrijeme suvremena graditeljska praksa u Palestini inkorporira mnoga tradicijska estetska obiljeżja. No ta se praksa neprestano mijenja s napretkom tehnologija i novih graditeljskih tehnika. Novi materijali i nove tehnike imaju velik utjecaj na tlocrte, veličinu i forme građevina. Uvođenjem novih materijala, npr. betona i cementa, tradicijski načini gradnje postaju zastarjeli i neisplativi, a javlja se i problem nedostatka kvalificiranih radnika. Ipak, unatoč novim građevnim materijalima danas su u Palestini kamen i beton i nadalje najčešce korišteni građevni materijali.

Kako je već prethodno spomenuto, Palestina je oduvijek bila poprište migracija, okupacija, izbjeglištva, kriza i ratova. Mnoge su tradicijske građevine uništene. Nakon izraelske okupacije 1948. i 1967. velik je dio palestinske populacije bio prisiljen pobjeći iz Palestine i napustiti svoje gradove, sela i domove. To ukazuje na potrebu cjelovitos istraživanja i analize tradicijske arhitekture i tradicijskih načina gradnje u Palestini jer oni polako nestaju. Stoga je vażnost takvih istrażivanja vrlo velika. Ovaj rad predstavlja samo jedan dio povijesnog i kulturnog naslijeđa Palestine s ciljem analiziranja građevina i graditeljskih tehnika, pri čemu su se koristili lokalni materijali kao što su kamen, drvo i blato/zemlja koji se danas smatraju ekološkim materijalima.

\section{BIOGRAPHY}

BIOGRAFIJA

MUmen ABUARKub, PhD, was born in 1965 in Dura, Palestine. He received his BSc, Master degree and PhD from the Faculty of Architecture "Ss. Cyril and Methodius University" in Skopje and is currently at postdoctoral studies in Architecture and urbanism at the Faculty of Architecture at Zagreb University. He works as a professor at the Faculty of Architecture at MIT and FON Universities in Skopje and Union University - Nikola Tesla in Belgrade.
Mumen ABUARKub, rođen je 1965. u Duri, Palestina. Završio je preddiplomski i diplomski studij te doktorirao na Arhitektonskom fakultetu „Sveučilište Sv. Ćirila i Metodija" u Skopju. Polaznik je postdoktorskog studija arhitekture i urbanizma na Arhitektonskom fakultetu Sveučilišta u Zagrebu. Zaposlen je kao profesor na Arhitektonskom fakultetu na sveucilištima MIT i FON u Skopju i Union sveučilištu - Nikola Tesla u Beogradu. 
